2020-08

\title{
Regenerating Unfinished Buildings
}

\section{Troiani, I}

http://hdl.handle.net/10026.1/16406

John Wiley \& Sons

All content in PEARL is protected by copyright law. Author manuscripts are made available in accordance with publisher policies. Please cite only the published version using the details provided on the item record or document. In the absence of an open licence (e.g. Creative Commons), permissions for further reuse of content should be sought from the publisher or author. 


\section{Author Queries}

\begin{tabular}{|l|l|}
\hline AQ1 & Please note that the References "Papadimitriou (2014)" has been cited
\end{tabular} in the text, but not in the list. Please check and provide the reference details. 


\section{Regenerating Unfinished Buildings Igea Troiani 1 Andrew Dawson ${ }^{2}$}

${ }^{1}$ University of Plymouth, UK

${ }^{2}$ Original Field of Architecture, Oxford, UK

\section{Introduction: Unfinished Buildings in an Age of Uncertainty}

\section{It seems clear that somehow we [architects] should be able, when given the impossibly difficult problem of designing in two weeks a city for three million people, to respond with vigor and skill.}

(Koolhaas, quoted in Owen 2009, p. 1)

In the 1990s Rem Koolhaas began to contemplate "how global capitalism ... created dynamic, highly speculative urban conditions that were transforming the contemporary city' (Dunham-Jones 2014, p. 150). With the end of the cold war, capitalism had emerged as a victor and as neoliberalism began to sweep the world post Margaret Thatcher and Ronald Reagan, architecture and urban utopias sprang up at a frenzied rate of speedy construction and, sometimes, at vast scales. From Europe to North America, South America, Asia, Africa, and India, a building boom fed by freely available loaned capital and a neoliberal drive now instilled in most developed and developing countries has meant that everyone (who can) wants to be a developer and everything (that can be) is a development opportunity. No longer the enemy of the elite architect, land and speculative construction that captures new markets signals a healthy architectural business. Understanding the importance of 'the economics of architecture', Koolhaas (quoted in Lubow 2000) encouraged architects to take on as many commissions as possible, stating, 'you can never say no, because there is someone behind you who will say yes'.

But as William Mangold (2014, p. 23) notes, architecture and design have always had a 'tricky' relationship with capitalism because they are dependent on it and 'subject to exploitation because of it'. Buildings cost money to build and therefore 'construction - and within it, architecture - necessarily works for and within the monetary system' (Deamer 2014 , p. 1) with positive and negative repercussions. While architecture has always been subject to boom-bust cycles, the economic crash of 2008 is an important pinch point in global development to research because architects nowadays are having to work faster, be more productive, and work at much larger scales and in shorter time frames than before. After the 2008 crash, there was an unprecedented amount of building stock that was affected 
by the stop in the flow of available capital. In many cities worldwide an abundance of unfinished buildings emerged. Unlike other periods of downtime, the problem being encountered in the post-2008 period was the vast number of unfinished buildings and cities that had sprung up quickly since the heady 1990s and which now littered many parts of the world. This may also occur after any economic downfall resulting from Covid-19. While one might argue, as Rumiko Handa (2015, p. 7) has, that 'the notion of complete, perfect, and permanent architecture ... [is] a fallacy', buildings that are partially built development sites which lie dormant for lengthy periods of time deserve close study by architects.

Unfinished modern buildings have emerged as a strand of global contemporary architectural research because "both the practice and the discipline of architecture face an economic, social, and political landscape vastly different from the one that greeted them in the early years of the 21st century' (Flowers 2014, p. 2). Moments of crisis recognise that 'architecture cannot carry on as usual; to remain relevant requires not only that we reconsider the changing conditions, but that we also act' (Ballesteros et al. 2008, inside cover). In an age of uncertainty, incomplete buildings 'afford architecture a valuable moment of selfreflection' (Flowers 2014, back cover). They allow architects to reconsider the profession's historical commitment to the perpetual production and consumption of new buildings. Because they are a building fragment they draw attention towards regeneration, rather than generation. For regeneration, the environmental, material, historic, and social legacies of unfinished buildings and cities need to be understood within the design process. Unfinished buildings allow architects to reconsider the needs of economically affected local communities and to explore the use of a rawer, sometimes more frugal, design approach that responds to the rawness and design of the found building fragment.

The subject of this chapter is the stock of buildings that are stopped part of the way through construction, in particular unfinished modern concrete architecture built up to a skeletal frame stage. Unlike the 'ruins of once-completed structures', unfinished contemporary buildings sit in limbo having never been fully realised or used as they had intended to be (Virilio 2008, p. 207). And unlike the ruins of incomplete historical buildings that are, according to Dalibor Vesely (2006, p. 43), a physical fragment and 'ontological synecdoche', unintended incomplete structures tell of a different relationship between a part and its whole. Unfinished modern concrete carcasses, the staple component for quickly built, highly dense, economical high rise construction, have become material waste. As a form of urban debris, unfinished structures are telling of the perils of uncontrolled capitalist production, consumption, and wastage. The defunct, dormant construction sites that are commonly boarded up impact negatively on the everyday life of those passing them. Often seen as eyesores by the public, they continue to remind communities of economic crises and cultural failure (Van der Hoorn 2009). Younger generations of architects who suffer the brutal side effects of the capitalist project gone wrong can often find themselves unemployed, with unsure futures and/or unmanageable debt.

This chapter seeks to explore the positive outcomes that can emerge for architectural practitioners from moments of economic crisis where the wasted capital invested in unfinished buildings is capitalised upon environmentally, socially, and politically, and not solely for economic gain. While this research focuses mainly on the case study of Athens, the urban regeneration research presented here aims to inform other parts of the world containing unfinished building stock by offering generally applicable regeneration solutions. 
Even though other scholars, discussed later, have endeavoured to study the potentialities of particular unfinished buildings and cities in other countries, this research makes a unique contribution because it creates a toolkit of design strategies to regenerate the unfinished with a focus on the global and the local, and on the collective, not the self-oriented neoliberal, individual. In addition, the research is not solely concerned with the scale or form of the building or the city, i.e. its architectural composition, but is positioned to consider human existence in the world at large and in the wider ecology in light of what appears to be a full-blown acquiescence to capitalism. For this reason, Felix Guattari's (2014/1989) book The Three Ecologies, which sets out an 'ecosophy' (or ecological philosophy), is used as a foundation for considering design regeneration practice for unfinished buildings. Guattari's speculations on the links between capitalism, consumption, production, and ecology at a philosophical level and Jane Bennett's (2010) research on vibrant materialism - which embodies politics within things - shifts our gaze from a solely material world view to an immaterial world view. Aligned with Douglas Spencer's (2016) critique The Architecture of Neoliberalism: How Contemporary Architecture became an instrument of Control and Compliance, the argument presented here is for a socio-political driven mode of regeneration practice applied to unfinished buildings and cities that creates a better balance between the natural, social, and material worlds in which we live. The design proposals, produced in a university studio not practice studio, occupy a fictional, unrealised realm but with strategies that are transferable to the practice workplace.

The unfinished buildings research presented here defines first, the field of visual and design research on incomplete modern concrete buildings globally and positions our research on unfinished buildings that began with 'Unfinished Athens'. Second, it outlines the emergence in modern architectural history of the maison domino frame building (the modern concrete frame) and its evolution worldwide, and specifically in Athens, into the popular polykatoikia (apartment building). Third, it focuses this design research on incomplete concrete buildings in Athens and defines five design strategies and tactics for how to approach the site-specific regeneration of an unfinished building. Using Athens as a case study, the research responds to the questions: How can the architect's practice influence local communities affected by the crisis in the city and improve the wellbeing of locals and their urban landscape? How can architects work positively towards architectures of additions in Athens and beyond?

\section{Research on Unfinished Buildings: From Venezuela to Italy, to Greece and Beyond}

'The aesthetic of the unfinished' emerged with the Renaissance, most notably in the work of Leonardo da Vinci and Michelangelo, who 'were plagued at various points in their careers by an inability or lack of will to bring certain of their paintings and sculpture to completion' (Levine 2006, p. 342). While the term non finito was coined by Georgio Varsari in a manuscript on the artist to describe Michelangelo's 'Slaves' or 'Captives' dated 1513-1516, it came 'to serve as a sign of modern ideas of suggestiveness, ambiguity, and subjectivity' with romantic connotations (Levine 2006, p. 342). Neil Levine (2006, p. 342) contends that 'the unfinished ... revealed the difficult transaction that takes place in art between the 
unknown and the known, between the abstraction of thought and the material demands of brute matter'. In architecture and urban design, the difficult transaction between the unknown and the known, between design and building, between incompletion and completion is simultaneously in the hands of the designer and beyond their control, particularly in times of economic uncertainty and flux. And like the unfinished painting or sculpture, 'the aesthetic of the unfinished' modern building has visual and phenomenological allure for many artists, photographers, filmmakers, architects, and urban designers worldwide. Having been absorbed into popular culture through dystopian scenography, the abandoned and incomplete contain forgotten, unknown, and sometimes scandalous histories. 'Buildings tell stories, if they're allowed' and because architects and artists have become more involved in relaying those stories to culture at large, unfinished buildings, unlike vacant sites, can present the beginning of a design story that can be critically added to (Brand 1997, p. 4). Recording the chequered history of an unfinished building is vital when devising regeneration strategies and is an essential step in understanding the building's design logic, failure to be procured, site specificity, and unique cultural, political, social, and economic context.

A study of unfinished modern buildings in countries experiencing economic recession, decline, slowdown or withdrawal of money reveals social, political, cultural, and architectural difference specific to place. Whether designed by architects or not, the incomplete concrete skeletons present a range of different typological structural frames (mostly following a Cartesian grid), which offer varying design and social futures. The building lifecycle of unfinished concrete frame buildings can be longer than other load-bearing buildings because of the flexibility and versatility of the construction system. As long as the structural components are sound, concrete frame buildings can be stripped back and remodelled over and over again or simply put on hold and developed further at a later stage.

Arguably one of the most well-known recent unfinished, unoccupied buildings is the Torres David or Tower of David, made famous through the research, exhibition, and film, Torre David: The World's Tallest Squat (Kneer and Schwartz 2013) by Zurich-based multi-disciplinary design practice Urban Think-Tank (U-TT). Torres David was originally designed to become the Centro Financiero Confinanzas, a 45-storey skyscraper for bankers in Caracas, Venezuela. It is the incomplete utopian dream of developer David Brillembourg. Abandoned in 1993 after Brillembourg's death and the collapse of the financial group supporting its construction, the Torres David sat dormant in the city until, like the plot of a dystopian film, it was taken over by around 800 families comprising 3000 squatters. U-TTs research celebrated its informal occupation and the tower modifications by its illegal occupants as a heterotopia or 'ambiguous space' (Fuenmayor 2011). U-TTs founder architect, Alfredo Brillembourg, a relative of David Brillembourg, in collaboration with U-TT co-founder Hubert Klumpner and photographer Iwan Baan, visually documented the new vertical communities and their social life within the building and argued for more humanitarian and sensitive regeneration which would allow the residents to remain in the building. In Torre David: Informal Vertical Communities (Brillembourg and Klumpner 2012) Andre Kitagawa with U-TT present 'Torre: A Graphic Novella' through which to record the history of the building and its informal occupation, and combined with a visual plethora of seductive photographs, U-TT present a light-touch, modest design. U-TT propose mostly infrastructure or service architecture interventions including a new 
vertical mobility system, sustainable energy production and storage systems, additional commercial spaces for residents, a new water supply infrastructure, façade improvements, better waste disposal conduits, and hydroponic gardens. 'Interventions would ... be implemented in phases, making a gradual, step-by-step transition and enabling the residents to continue to invest "sweat-equity" in Torre David' (Brillembourg and Klumpner 2012, p. 347). The project remained unrealised and the Venezuelan government later evacuated the families under Operation Zamora 2014, wanting instead to facilitate the purchase of the building by a Chinese consortium interested in completing the office tower to the original design, which has also since fallen through.

Using similar methods of visual research, since 2006 in Italy, the Alterazioni Video (Art Collective) has been cataloguing photographs and mapping the location of hundreds of unfinished public buildings scattered across the country. Included in the documentary Unfinished Italy (Felici 2011), their Incompiuto Siciliano or Sicilian Incompletion project records a range of unfinished public buildings (not housing) in Giarre, most of which were designed by architects (Alterazioni Video 2008; Di Girolamo 2008). As explained in the documentary, their incompletion was due to lack of finance, although sometimes the buildings were designed erroneously by the architect (a pool that is not the correct length or a polo stadium in a country that only knows polo as a designer clothing brand) or never meant to be finished - instead only built in order to feed a corrupt construction industry. Reflecting in part on alternative uses for some of these sites, the Alterazioni Video proposes a critical but less obtrusive, noninterventionist participatory regeneration festival project entitled The Archaeological Park (Masu and D’Aita 2010). As artists, Alterazioni Video present Incompiuto Siciliano as a new architectural movement in Italy that produces instant ruins (useless architecture) that represent Italy's productive inadequacies over the last 50+ years. For Alterazioni Video, unfinished buildings are symbolic of a lineage of Italy's historical ruins and of a country that has been in sustained political turmoil and economic decline. The artists see the architectures as a new style that should be left in its original state, as a poetic cultural gesture. Several other European countries have taken a more proactive position on regeneration of unfinished modern buildings whether they are architectural icons or not.

In Athens, design research has been undertaken on the architecturally significant unfinished office Tower located at Piraeus harbour. The Piraeus Tower 2010: Changing the Face/Facades Reformation competition run by GreekArchitects.gr (GRA) aimed to explore how architectural redesign of this empty concrete skyscraper shell could reform the urban environment. The editors of the competition book explain: 'The starting line for the competition notice was the need for replanning an uncompleted since the 1970s office ... building where the down[stairs] floors are used for commercial purposes. The skeleton of [the] building is constructed from reinforced concrete and it is organised in a typical way - a vertical core with floors in horizontal layers. The growth of [the] building's volume results thus from the natural limits of skeleton and its position in the plot' (Mistriotis and Vandoros 2010, p. 8). Some of the competition design proposals reclad the concrete carcass, adopting sustainable strategies that capitalise on strong winds on the site or use vertical gardens or sheaths of water to rejuvenate environmentally and aesthetically the abandoned building. The competition did not result in a project that was realised, leaving the Piraeus Tower as a derelict concrete carcass in limbo. Nevertheless, 
design research into the problems with architectural production in Greece since 2008 has garnered wider international interest, particularly through the architectural design studio.

The research project Labor, City, Architecture: Towards a Common Architectural Language, led by Pier Vittorio Aureli at The Berlage Centre for Advanced Studies in Architecture and Urban Design in the Netherlands, explored how 'urban form in Athens produces a commonplace habitat' (Aureli 2011). The second-year postgraduate studio run between winter 2010 and spring 2011 examined the liquidity of Athenian society, 'the politics of labour in relation ... with the city-form' (Aureli 2011). Focusing on the Kerameikos and Metazourgeio districts, the design projects engaged with the scale of the individual unit to form a larger common complex based on the typologies and taxonomies of the urban forms in Athens, including the polykatoikia. While not focused on unfinished buildings specifically, the research led Aureli to conclude that in contemporary Athens 'design is not enough, and that it might be necessary for architects to abandon the idea of the project in order to engage the urban totality' (Aureli 2013). In 'On Conflict, Generic and the Informal: the Greek Case', Platon Issaias identifies that 'the Greek city allows us to rethink the distinction between "formal" and "informal” urbanisation' (Issaias 2016). It is from this space of flow between formal and informal architectural practice in relation to development that the wider research project on unfinished buildings sprang, starting with a study of the possibility of unfinished buildings in Athens or Unfinished Athens (2014-2015), then research into the 'ghost urbanisations' on the outskirts of Madrid, Unfinished Madrid (2015-2016), to the fictional regeneration of derelict public buildings and new towns in Cuba that were halted due to the end of the Cold War, Unfinished Cuba (2016-2017). Here Unfinished Athens is discussed in detail but general conclusions about regeneration strategies for unfinished modern concrete frame buildings are made drawing on all three pedagogical design research studios which we led, in light of the ongoing and increasing research emerging in this field of study. Athens was chosen for the initial study, because it was at the time suffering severely from the aftermath of the fiscal crash, and also its history links the emergence of the modern concrete building frame, the maison domino, back to the Greek temple and forward to the national Greek housing typology, the polykatikia.

\section{The Evolution of Concrete Frame Construction: From Maison Domino to Polykatoikia}

In the summer of 1911, Charles-Édouard Jeanneret (better known as Le Corbusier) travelled to Athens. He spent three weeks visiting the Parthenon every day, sketching the elevated horizontal podium and the columns springing from it (Benton and Cohen 2008, p. 56). He drew column grids in plan and details of column and horizontal floor plate connections in the temple. Only three years later, in 1914, Jeanneret, then aged 27, inspired by the Classical temple, conceived of the maison domino as a mass-produced reinforced concrete construction system to provide housing relief for victims of the First World War (Emmons 2012, p. 133). Max Du Bois, who was Le Corbusier's partner in the Domino House, had given the architect a book on concrete construction and translated it into French. The system was based on the horizontal concrete slabs supported by columns and joined by cast 
concrete stairs, and was presented as the minimal structural frame to the owners. 'It was self-described as the "rationalization of building production" based upon the scientific efficiency principles of Taylorism' (Emmons 2012, p. 132).

'The first multi-storied apartment buildings were built in [Athens in] the 1910s, shortly after the introduction of the reinforced concrete technology in Greece' (Dragonas 2014). But it was in the period between the World Wars that Greek architects - connected to the pioneers of the Modern Movement - invented their own version of the domino house and the polykatoikia emerged as a model for middle class housing. The polykatoikia is a form of communal housing based on the domino house construction system, designed in response to the crisis of an influx of refugees into Athens from Asia Minor from the 1920s (Kotzamanis 1997, p. 5). In 1929 Athens adopted a law of horizontal property, which entitled:

the owner of a plot $[\ldots]$ to be compensated by the contractor who builds [apartments] on his land. This unique property-swap system received tax privileges and soon became the principal method of real estate transactions in Greece.

(Dragonas 2014)

The contractual system known as the antiparochi involved private contracts between individuals, 'multiply[ing] to the extreme the dominance of private property, but also replaced advanced capitalist methods of financing in the building sector' (Issaias 2016). According to Aureli et al. (2012) the State envisioned the polykatoikia would allow the nurturing of local, flexible systems of building. This deregulation set the scene for a bottom-up system of small-scale self-building for speedy economic recovery, 'with minimum state intervention' (Kazakos 2009). Architects had limited involvement in the production of polykatoikia (Philippidis 1984, p. 310; Theocharopoulou and Frampton 2017). As a dominant urban typology, the polykatoikia was a form of informal, self-build in Athens that has since pervaded the city's character and morphology. Since its inception, and in light of Greek legislation, the polykatoikia is often only partially built, with the intention of adding more floors on later. While it is an unfinished building typology typical to Greece, the incomplete concrete frame tower, intended for housing or commercial use globally, exists in many other cities. The attraction of the 'aesthetic of the unfinished' that emerged in the Renaissance continues as a zeitgeist in many countries and drives the visual, cinematic, and design research into design tactics for unfinished modern ruins in Athens.

\section{Design Tactics for Unfinished Athens}

The downturn in the market from the 2008 economic crash has had varying effects on countries worldwide. In Europe, the economies of the EU member countries Portugal, Ireland, Italy, Greece, and Spain (PIIGS) were hardest hit. Of these, Greece, arguably, was initially most unable to refinance its government debt with dire and drawn out consequences for citizens, architects, and architecture. It is for this reason that our research on unfinished buildings began in Athens in 2014. Between 2008 and 2014, architectural practice had virtually come to a standstill in Greece, resulting in large numbers of unemployed Greek architects. Unable to work in Greece, some left to practic 
architecture elsewhere or moved to other modes of work outside architecture to sustain a livelihood. Unfinished A thens was a d esign s tudio that sought out research m ethods and design labour strategies to generate work in a climate of low capital investment. It was not driven by economic imperatives but instead sought to understand how regeneration building design practice can regenerate communities. In this sense, we read the city of Athens as much as a site of 'human and social discourse', after Henri Lefebvre, Guy Debord, and Michel de Certeau, and as 'a social product' (Crawford 1999, p. 10) for everyday use.

Unfinished Athens is an architectural, urban, environmental and socio-political regeneration project concerned with everyday urbanism. As design research, it maps and records - using site walking and urban exploration (Garrett 2013), photography, video-making, interviewing, and cartoon drawing - unfinished buildings in and around Athens built pre and post 2008. It examines the effect of the unfinished buildings on the everyday urban life around them and speculates on their transformation. Unfinished Athens unlocks the possibilities of this underutilised building stock by presenting some design tactics brought from emerging unconventional scholarship and practice. Yona Friedman's contention (in Brillembourg and Klumpner 2012, p. 25) that 'the problem is not architecture. The problem is the reorganisation of things which already exist' frames the design research. A primary aim of this design research was to practice environmental reuse to short-circuit building production and consumption by 'changing buildings [rather] than ... build-ing new ones' (Brand 1997, p. 5). The research considers architectural design within a long-term cycle and as a fluid process of creation and recreation (akin to Thomas Coles' The Course of Empire, 1833-1836). Other aims are to heighten modernist architecture's relationship to nature and ecological concerns expanding Guattari's concept of 'ecosophy'; to question the scale of design intervention in relation to social agency; to question architectural agency, design authorship, public engagement, private ownership; and to use local social and political life, its memories and practices as architectural design resources.

In setting up this practice-based design research studio, we established - through the kind assistance of Konstantinos Papadimitriou, with whom we collaborated to curate the touring exhibition Unfinished Athens - connections with Greek researchers of unfinished buildings, Katerina Zisimopoulou and Manolis Oikonomou. Zisimoupoulou's work in Glyfada and the research in Piraeus by Oikonomou informed our fieldwork. The research by Orsalia Dimitriou enhanced our understanding of the social and urban particularities of Exarcheia. The work of British political economist Philippe Legrain, Greek-born British economist Vicky Pryce, and others informed the architectural designer's understanding of the history of the financial situation in Greece over the previous 20 years.

Regardless of concerns expressed by the European Central Bank that Greece may not have fully disclosed its financial state, in 2002 Greece joined the Eurozone and began to use the euro as its main currency. By March 2004, when Prime Minister Konstantinos Karamanlis came to power, it became apparent that Greece had a budget deficit of $8.3 \%$ rather than the reported $1.5 \%$ (Melvin 2015). So as to conceal bad debts and to advance its economic stature, Greece bid for and won hosting the Olympic Games, which were held in the summer of 2004 in Athens. During that time, Greek developers and construction companies, with easy access to cheap finance, embarked on a neoliberal frenzy of construction that varied from legal to illegal development. Deemed by government to have made an economic surplus, the supposed profitability of the games was soon negatively 
impacted by the US financial crisis of 2007. As a result, many opportunistic developments stopped midway, leading to a plethora of partially built buildings scattered in and around Athens. The already large Greek deficit made the country particularly vulnerable and as tax avoidance grew, Greece became precariously close to defaulting on its debt repayments, requiring international lenders to bail the country out. In 2010, the European Commission, the European Central Bank, and the International Monetary Fund (IMF), or the Troika as it is known, stepped in to lend money, at the same time setting out restrictive economic conditions which resulted in increased unemployment of 50\% and public protests (Melvin 2015). In June 2015 Greece defaulted on its payment to the IMF and there was concern it would leave the Eurozone. Since 2015, however, European countries and private investors have undertaken the biggest financial rescue of a ny c ountry to $d$ ate by loaning Greece 294.7 billion Euros (Amadeo 2018). Battling repayments and contesting austerity measures instated by Europe have been the main challenge for the country since and have resulted in a reduction of public welfare services and pensions. Greece remains debilitated by heavy bureaucratic processes and unclear property rights which have prevented the selling off of state-owned assets, and led to growing tax evasion, an underground, black market economy, and increased uncontrolled immigration.

In terms of immigration, Greece has experienced a steep increase in foreign populations moving to the country. Between 2012, Albanian, Turkish, Iranian, Iraqi, Somali, and Syrian migrants (legal and illegal) have added pressure to the already strained public services and economy of the country. Homelessness among the lower- and middle-class Greek population increased post 2008 because many Greeks, having lost their jobs, defaulted on paying their own home loans. Coupled with the increase in migrants moving to Athens, public housing facilities and bureaucratic processes have been excessively strained to an extent that the socialist welfare state model has withered.

According to Spyros Themelis (2015), politics in modern Greece is unavoidable; it is an 'omnipresent and pervasive force in people's [daily] lives'. Themelis (2015) argues that 'This is precisely the biopolitics that Hardt and Negri (2000) talked about'. In Empire, post-Marxist philosophers Hardt and Negri (2000, p. xi) discuss their witnessing of 'an irresistible and irreversible globalisation of economic and cultural exchanges' that is 'materialising' empire. Empire is concerned with how political control is exerted through capitalist production and consumption, and examines ways to resist the totalisation of the global empire and its economic force on countries (such as Greece).

The 16 projects undertaken as part of this design studio-based research project by Greek born and nonGreek born graduate architects engage with the reuse of found unfinished concrete skeletons located during a fieldwork visit to Athens in September 2014. In collaboration with cinematographer Konrad Welz, the buildings in the districts of Omonia (Figure 9.1), Metaxourgeio, Exarcheia (Central Athens), Glyphada, and the Port and Docks of Piraeus (Figures 9.2 and 9.3) were of various typologies, including the polykatikia. Some of the incomplete buildings chosen for regeneration were the consequence of the 2008 financial crisis, others were earlier fragment legacies of the withdrawal of government funding for projects. All are as-found 'vibrant matter' that testify to the link between the politics of ecology, things, and humans. Jane Bennett's theory of 'vibrant matter' builds on The Three Ecologies (Guattari 2014/1989) to reveal the quasi-agency of nonhuman materials. 


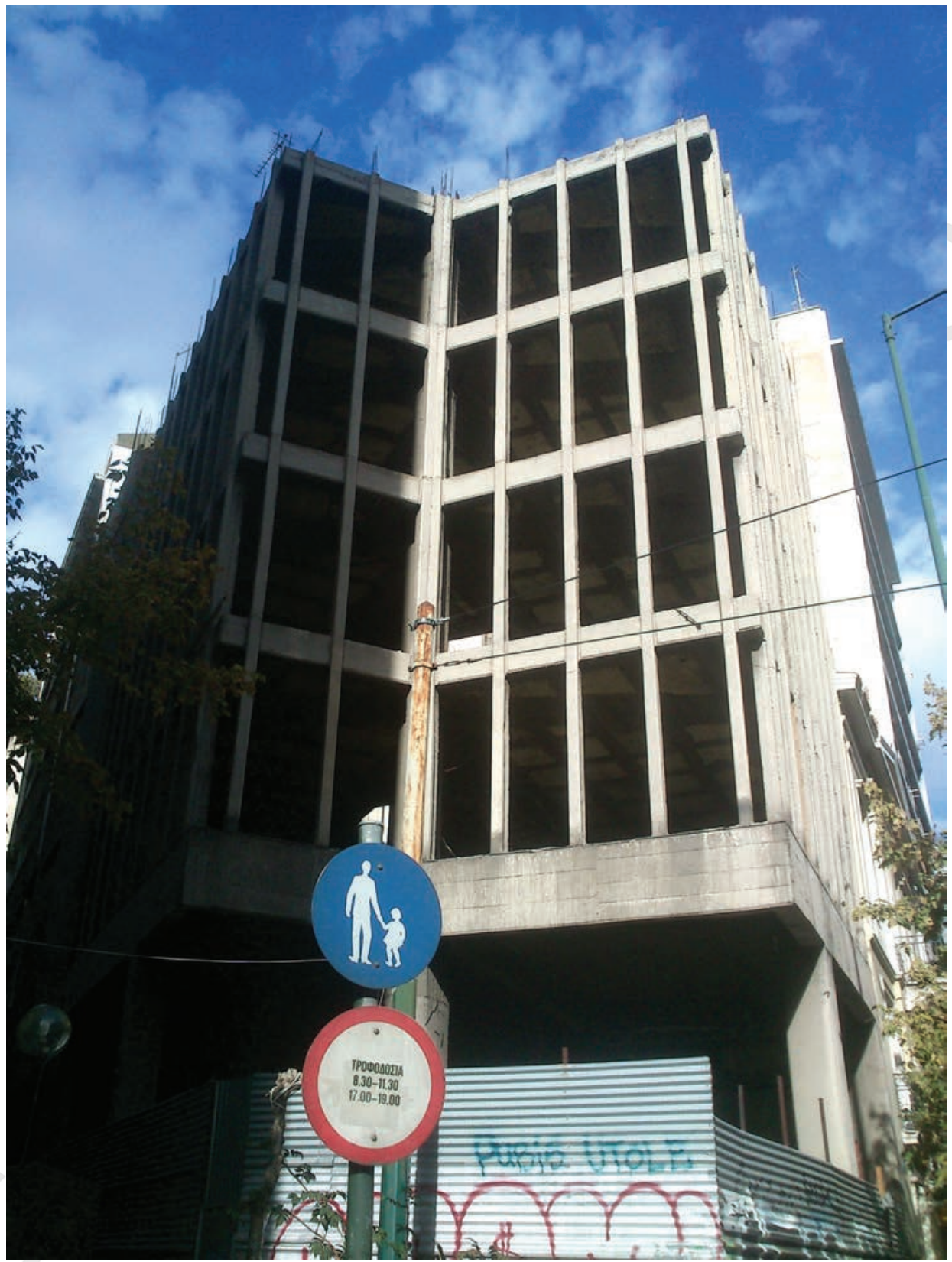

Figure 9.1 Exterior view of the unfinished polykatoikia in central Athens. Source: Photograph by Konstantinos Papadimitriou (2014). 


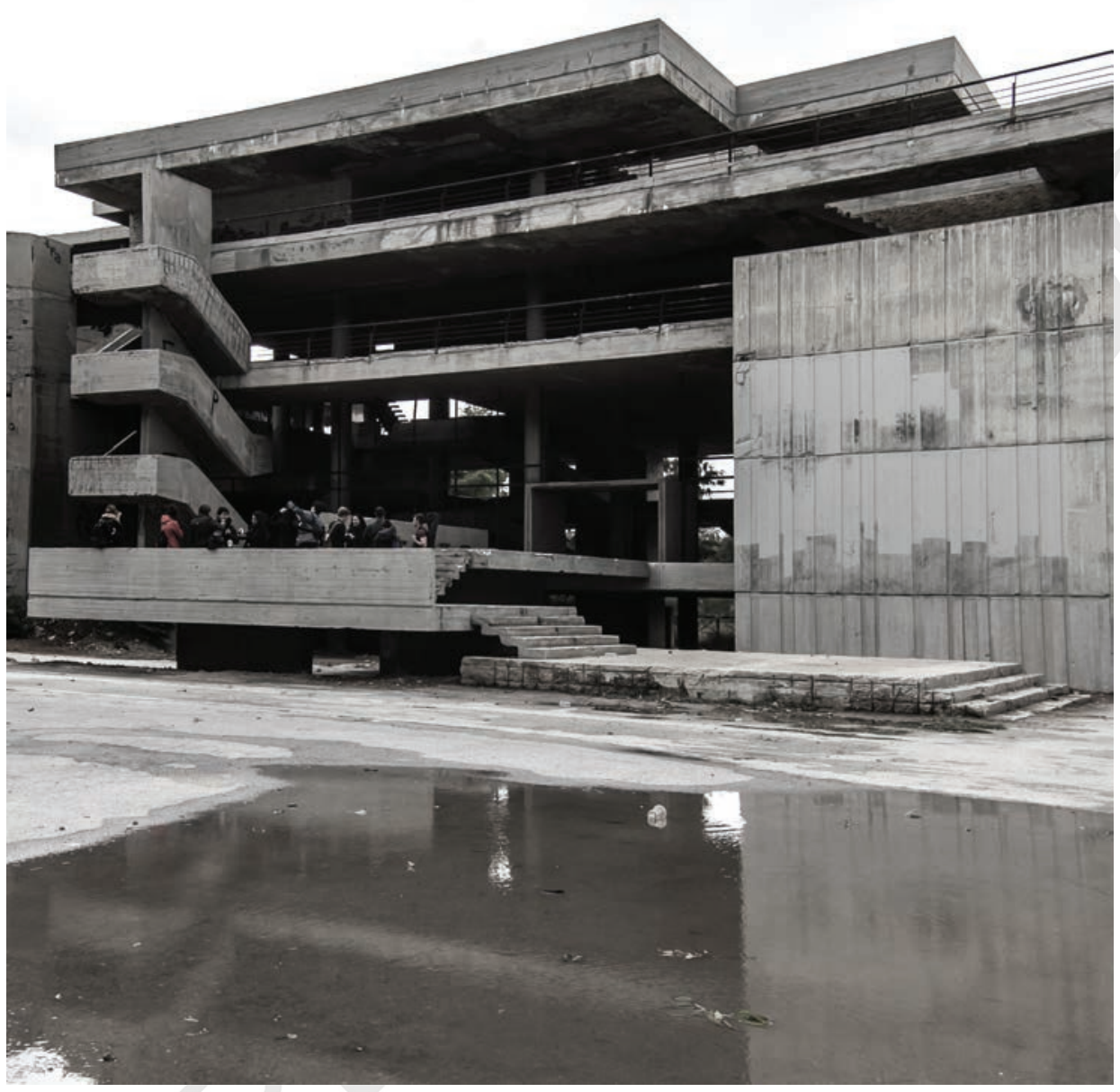

Figure 9.2 Exterior view of the unfinished Cultural Centre by Liapis. Source: Photograph by Konstantinos Papadimitriou (2014).

Bennett (2010, p. 113) takes from Guattari the definition of the problem as one of three 'ecological registers': the environmental, the social, and the mental, not solely the environmental. All three form a single whole which Guattari terms Integrated World Capitalism (IWC), a form of post-industrial capitalism. Guattari (2014/1989, p. 27) contends that the growth of IWC leads to 'the increasing deterioration of human relations with the socius, the psyche and "nature" and is "the result of a certain incomprehension and fatalistic passivity towards these issues as a whole, among both individuals and governments'. The engagement with 'these issues as a whole' and the quasi-agency of partially built buildings as Bennett's 'vibrant matter' forms the impetus for the five themes of architectural design approaches the postgraduate students adopted for Unfinished Athens: sustainable design, temporary buildings, socio-cultural engagement, design ethics, and socio-political activist critique.

The first design approach applies sustainable design strategies of 'superuse' (Van Hinte et al. 2007) and in-built design obsolescence for increased welfare provision. Purposeful 


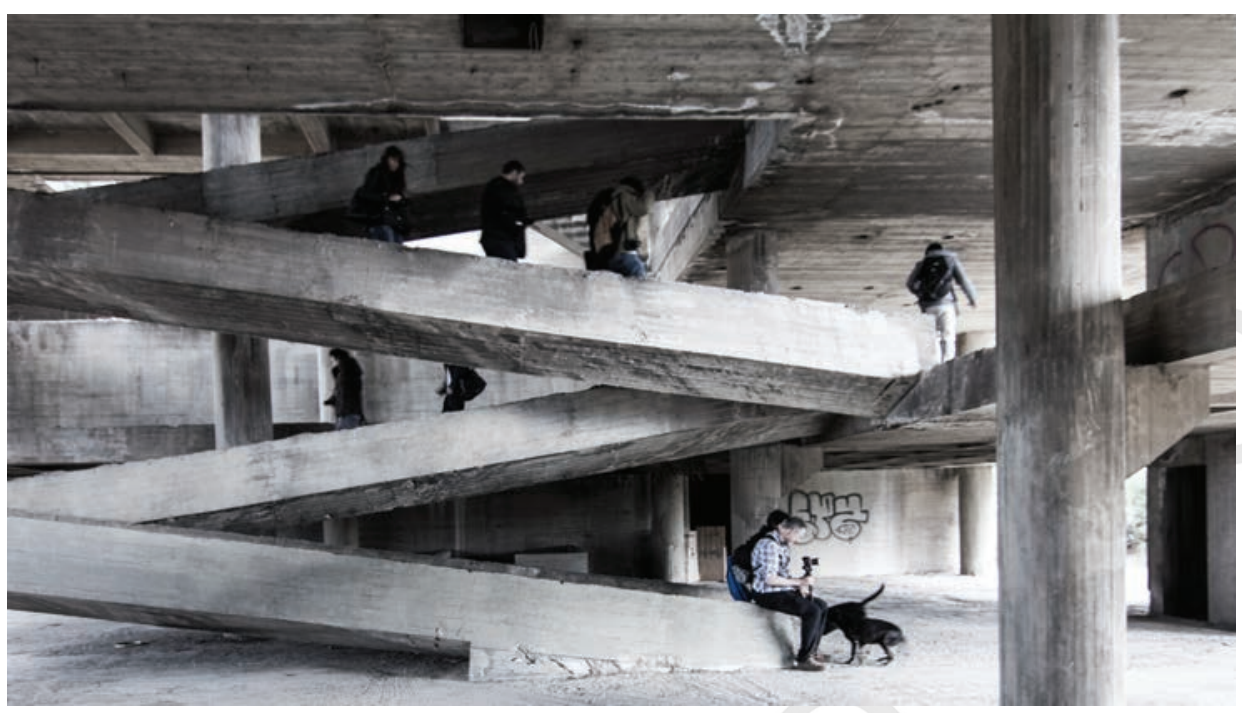

Figure 9.3 Interior view of student on the ramp of Liapis at the unfinished Cultural Centre. Source: Photograph by Konstantinos Papadimitriou (2014).

temporariness employing participatory methods of self-building are used in the second design approach to engage and include community participation in the regeneration of unfinished buildings. Thirdly, critical architectures of the incomplete are premised on cultural engagement with historical and traditional practices, where events and rituals direct architectural decision-making. Fourthly, the ethical position of architects in relation to the issue of the increase in immigrants residing in Athens is explored. Fifthly and finally, political and social commentaries and activism concerning place, capitalism, and the IWC are critiqued in the last approach to regeneration. An example of each tactical design approach is presented here. All the projects, however, engage with the larger life cycle of post-industrial capitalism in which architecture traverses serving the private and public sectors. All five are important because they offer potentialities through which to reconsider the place and role of the architect in the urban regeneration and development of unfinished, latent building stock in economically uncertain times anywhere in the world.

\section{Sustainable Design for Unfinished Buildings}

This design research was provoked by a set of paintings by the English-born American landscape painter, Thomas Cole. The Course of Empire is a series of five paintings created by Cole between 1833 and 1836. The paintings reflect on popular American concerns at the time towards the Empire, its power, and urban manifestation. The five paintings represent a five-stage life cycle rotating between The Savage State, The Arcadian or Pastoral State, The Consummation of Empire, Destruction, and Desolation. The Course of Empire animates the vibrant materialism that has linked politics and governance with the constancy of the construction and deconstruction of the city and nature (things) and citizenship (humans) through the concept of addition and subtraction. 
In Urban Transformations and the Architecture of Additions, Rodrigo Pérez de Arce (2015, p. xvii) identifies 'the recycling of architectural elements' in the city as one of three additive architectural strategies for engaging with urban design. In Unfinished Athens all of the designs recycle the concrete skeletons. Some utilise methods of panel prefabrication to infill and/or expand the existing building frame. Other projects use deeper harvest mapping of nearby recyclable material initiatives as design drivers. The concrete dominoframe skeletons undergo a life cycle transformation that can manifest as regeneration or degeneration. For instance, a project addressing the first theme of sustainable design, 'Expendable Athens' (Figure 9.4), proposes a playful, retro-styled urban environment that can be programmed and structured for change, based on an acceptance that buildings are not infinitely durable or permanent. The redesign of a polykatikia aims to deal with the problems caused by the economic crisis through the use of Archigram or Cedric Price style inspired plug-in modular units for housing, healthcare, and education. These units of social welfare services are inter-changeable, with limited shelf lives. At the same time, 'Expendable Athens' envisages the overgrowing by nature of the concrete skeleton, thereby accepting a form of uncontrolled 'uncivilisation' (Kingsnorth and Hine 2009) or Cole's Empire Desolation that simultaneously facilitates a paradoxical, optimistic post-war image of a collective Athenian future bringing together Guattari's three ecologies. This concept of understanding, valuing, and incorporating into the architectural design process the life cycle of a building at any stage between being unbuilt but conceptualised, partially built, built or decaying (De Silvey 2017), rather than working on tabula rasa sites with finite design outcomes, invites architects to expand their practice to work with sites at the various stages of their lives for long-term political, social, and environmental sustainability.

\section{The Temporary Design of Unfinished Buildings}

In the second category is 'The Imaginarium of the Incredulous' (Figure 9.5) by Marta Llorens Echegaray. It regenerates an incomplete public community centre that was designed by Greek architects in an expensive-to-build, elite, architectural Deconstructivist style. 'The Imaginarium' is a participatory platform for the local community. Pitched at the frugal rather than decedent end of architectural production, it invites Athenians to cultivate creative responses to the crisis that Greece finds itself in through self-building. The aspiration of the architectural design and the community building it to create a strong and permanent movement of urban justice. Managed by the Right to the City Alliance, 'The Imaginarium' is an interdisciplinary space for sharing ideas about what the city could be, and for collaborating to build that shared vision. It includes small-scale temporary self-build insertions using local materials that are sourced through harvest mapping. The community is invited to create the temporary insertions around the architect's rough design concept. The design strategy operates in much the same way the volunteer 'micro-brigade' housing construction program in Cuba has operated where the local community are involved in the construction process. As a form of collective action the 'micro-brigade' housing offers an alternative model of building procurement that challenges the neoliberal model of private property and self-interest with one of community ownership and collaborative production. 
$202 \mid 9$ Regenerating Unfinished Buildings

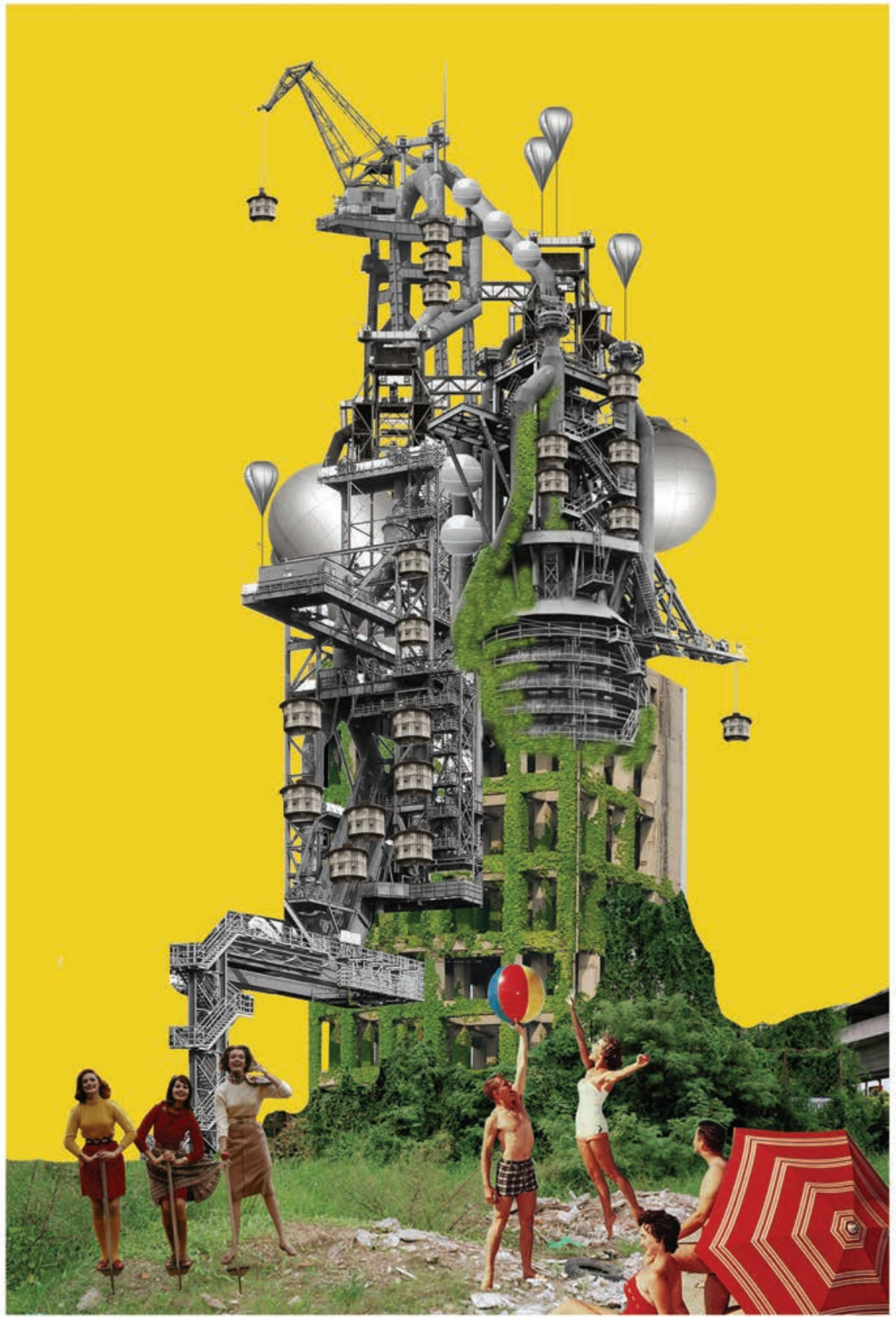

Figure 9.4 Nature's Reclamation of Unfinished Athens, Project title: 'Expendable Athens'. Source: Project by Ben Russell (February 2015). 


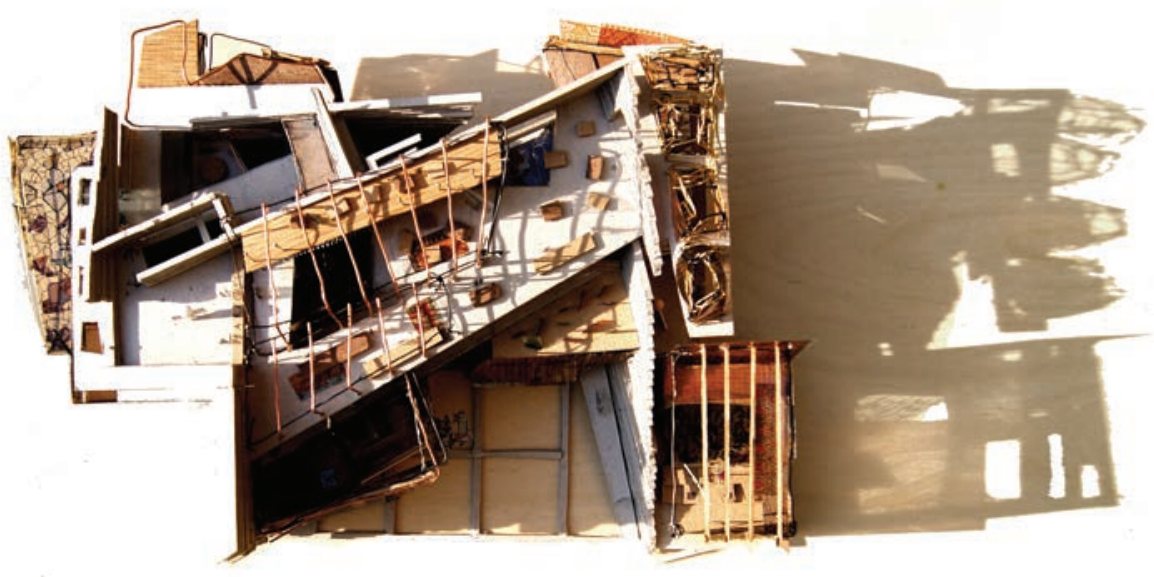

Figure 9.5 An Architecture of Participation and Imagination (1:200 physical model), Project title: 'The Imaginarium of the Incredulous'. Source: Photograph and project by Marta Llorens Echegaray (April 2015).

\section{The Socio-cultural Engagement of Unfinished Buildings}

Using traditional cultural practices of lost craft-making as a design protagonist, Pelagia Bourma's 'Tower of Lost Traditions' (Figure 9.6) creates a bold landmark where immigrants from all over the world can teach their culture and traditions to one another. The converted polykatikia is a place where each nationality living in Athens is celebrated through a variety of ritual activities enacted in the building. The proposal is a critique of globalisation, the global empire, and the conundrum of the loss of cultural identity of Greeks and foreigners. It is inspired by Guattari's socius, understood as a diverse cultural collective. Intersecting art and architectural disciplinary practices, the design aims to be a pioneering typology that explores new traditionally patterned façade skins motivated by traditional craftsmanship. Inspired initially by The Tower of Babel, the proposal purposely addresses the immigration issue in Greece for a globally conciliatory rather than nationalistic agenda. The empathic design and intended use proposes balancing social power relations, something strained within the Eurozone's delicate social mix.

\section{Ethical Design Practice for Unfinished Buildings}

Konstantina Faltaka's 'Mitos: Negotiating the Greek Bureaucratic Labyrinth' (Figure 9.7) engages with the social and ethical consequences of immigration in Greece. The rising number of migrants entering Greece inspired a design proposal that occupies an inner-city partially built polykatoikia. It examines the current legal framework for immigrants that forms part of the process for applying for Greek citizenship. Mitos educates foreigners about the Greek bureaucratic process, an almost unconquerable system. 


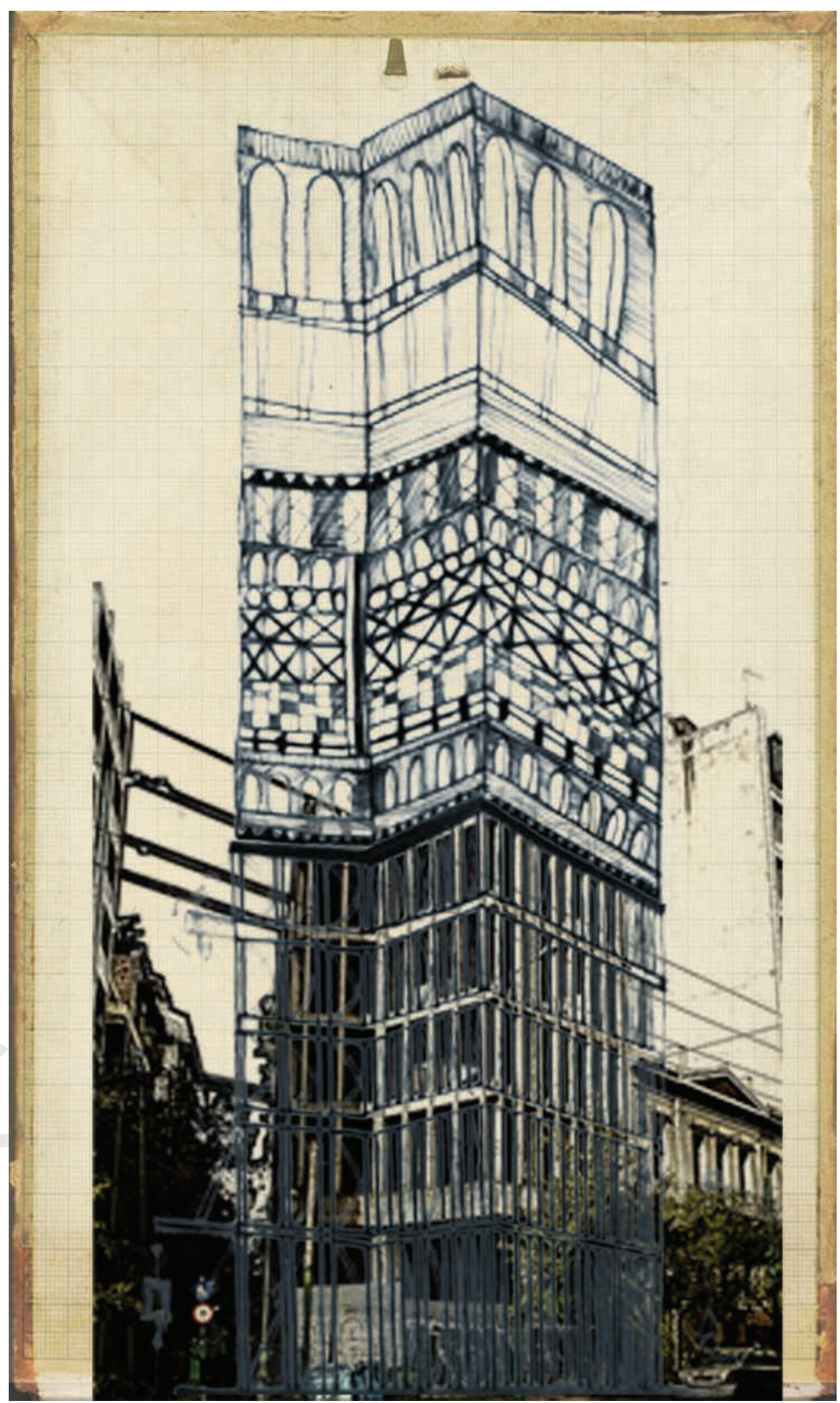

Figure 9.6 The Tower of Unfinished Memories of Culture, Project title: 'Tower of Lost Traditions'. Source: Project by Pelagia Bourma (December 2014). 

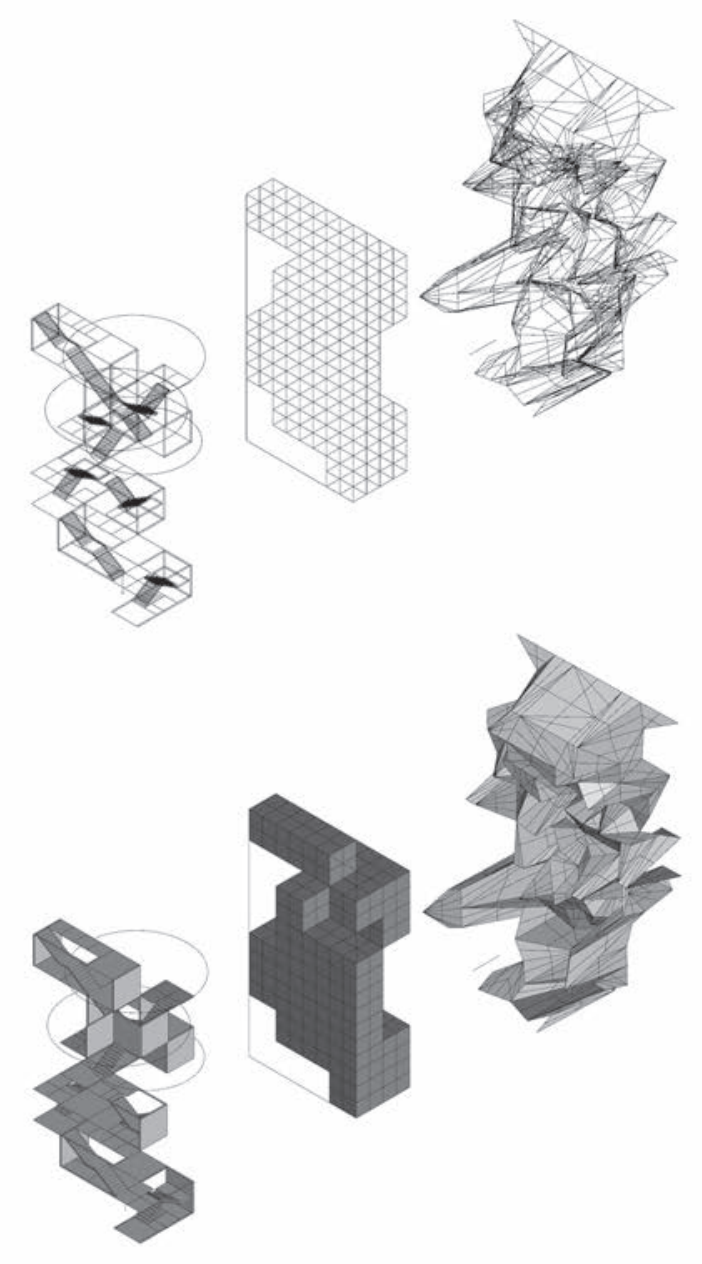

Figure 9.7 The Grid in Exchange with Labyrinthian Form, Project title: 'Mitos: Negotiating the Greek Bureaucratic Labyrinth'. Source: Project by Konstantina Faltaka (February 2015). 
The building provides a series of spaces that embody the curiously complicated administrative procedure of attaining citizenship represented as a labyrinth. The use of heavy bureaucracy, surveillance, and monitoring as a form of societal control, as analysed by Foucault (1977), underpins the socio-political critique of this design proposal.

\section{Socio-political, Activist Critique of Unfinished Buildings}

The final project provides social and political commentary on place, capital, and architecture's participation within the capitalist and Greek governmental systems. '4 Ideologies, 4 Towers' (Figure 9.8) by Geoffrey J Lan Hun Kuen investigates architecture's involvement in Greece's urban development through the design of four

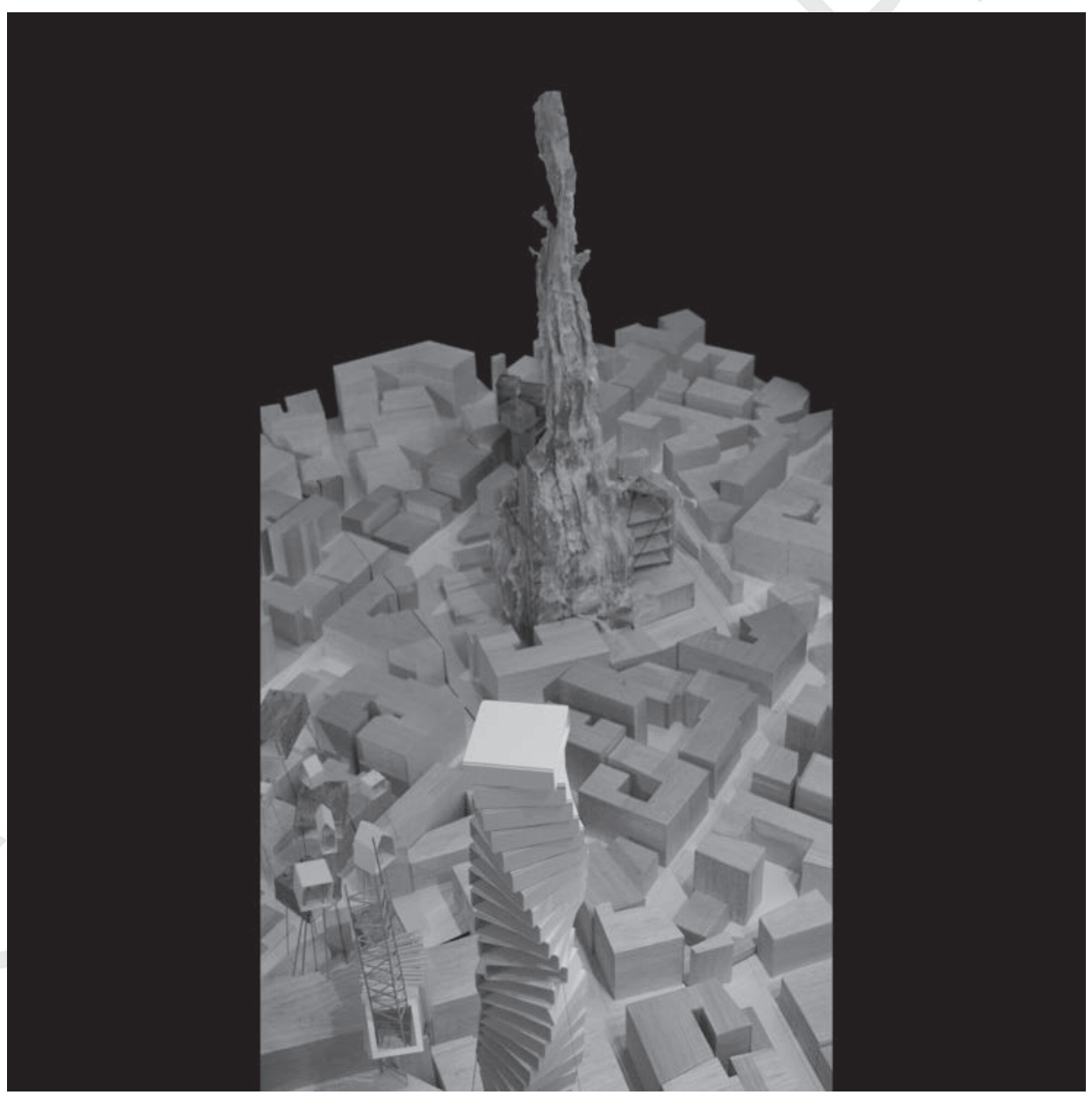

Figure 9.8 Photograph of physical model 1:200, Project title: '4 Ideologies, 4 Towers'. Source: Photograph and project by Geoffrey J Lan Hun Kuen (April 2015). 
corporate towers housing the headquarters of active political parties. Two of the towers are incomplete polykatikia. Referring to the works of Marx and Engels it offers a critique of the corporate tower as a machine for corporate production and questions architecture's scale of complicit involvement in the construction and destruction of Athens. The five design approaches of regeneration practice, while having to participate in a neoliberal model of IWC development, importantly offer critical reflections on Unfinished Athens.

\section{Conclusion: Reflections on Unfinished Athens and Architecture's Relationship with Capitalism}

In Turbulent and Mighty Continent: What Future for Europe? sociologist Anthony Giddens (2014) argues that Europe no longer seems so mighty; nowadays it is unable to impact upon world affairs because it is struck by turbulent and unstable political, economic, and social conflicts. With divisions arising across many parts of Europe including Brexit, social inequality, increased unemployment, inescapable debt, and unmanageable immigration to many southern European countries have shifted Europe from being a site of historical power to being powerless. The crisis of widespread austerity measures that followed the 2008 crisis has contributed to the urban decline of some European countries. This research has shown that the redesign and regeneration of unfinished buildings, the very product of failed neoliberal development endeavours, can act as 'urban catalysts' (Oswalt et al. 2013). This design research emerges from a grass roots methodology, inspired by reading ecology as a wider social, mental, and environmental condition.

In The Three Ecologies Guattari (2014/1989) identifies three lenses through which to understand urban environments that have gone into decline, namely social ecology, mental ecology, and environmental ecology. King (2011) notes that:

Guattari's argument $[\ldots]$ is that we have an erroneous conception of ecology, of environmental struggle, and that only by broadening our views to include the three ecologies will we be able to affect any enduring changes in our social/cultural/ natural environment.

The design research presented here aims to map, record, interrogate, and speculate on a selection of unfinished buildings in Athens through Guattari's three lenses rather than a solely environmental lens. The five thematic architectural design tactics presented - sustainable design, temporary buildings, socio-cultural engagement, design ethics, and socio-political activist critique - suggest that other modes of practice can be employed in situations of crisis resulting from uncontrolled, neoliberal speculation. Using frugal systems of unconventional design, many are already used by architects working in situations of humanitarian crises (Architecture for Humanity 2006, 2012). Operating in socially, politically, and economically volatile and fragile environments of any type requires architects to reconsider their attitude to the production and consumption of capital. Architects can turn to strategies of recycling, short life cycle, temporary or pop-up design. Projects that involve participation and engagement with the community present achievable modes of potential productivity. 
As Riether (2014, p. 57) argues in Lightweight, Impermanent, Recycled:

Small-scale temporary architectural injections into urban settings are a potentially appropriate approach to activating public spaces especially in a recession, when resources to realize expensive urban projects do not exist. ... For architects and urban planners, these small projects are certainly a welcome opportunity to challenge conventional approaches to constructing buildings or operating in a city.

Since Unfinished A thens, a n umber of d esign r esearchers, i ncluding $M$ atthieu Pratt, whose research project Kassandras (http://kassandras.rehab/about-us) occupies an unfinished polykatoikia, and the REFILL (Reuse of vacant s paces a s a d riving force for innovation at the local level) research group, have been exploring the possibilities of unfinished, a bandoned, a nd $\mathrm{v}$ acant $\mathrm{b}$ uildings a nd s paces i $\mathrm{n}$ s itu. A lfredo U TT applies the methodology developed in Venezuela to Athens and records in Reactivate Athens (Brillembourg et al. 2017) a five-month c ollaborative $r$ esearch $p$ roject b etween ETH Zurich and local partners in the city to reactivate public and abandoned spaces. Unlike Kassandras's practice-based use of their unfinished office as a live project workshop or the sociological findings by R EFILL (Jégou et a 1. 2016) or B rillembourg's excessively visual urban research, Unfinished Athens offers a critique of neoliberalism, proposing a toolkit of five design strategies for regenerating unfinished buildings within and beyond Athens. Seeing the problem of unfinished buildings as a global issue of the boom-bust cycle that drives and debilitates architectural production, this research was further developed in other cities and countries.

From September 2015 to May 2016 we undertook the research project Unfinished Madrid, which examined and applied the five design strategies to regenerate the 'ghost urbanisations' of El Quiñón, Sesena, and Valdeluz in Spain. The following year, from September 2016 to May 2017, we undertook research on unfinished buildings and cities as Unfinished Cuba, examining the possibilities for regeneration of unfinished nuclear power plants, nuclear cities, housing, and government buildings in a Communist country. Research in China examined the ways in which the country's rapid urbanisation in a 'socialist market economy' can negotiate the problem of incompletion using state funding. A series of publications have been generated which record the visual research findings of the mapping and design proposal research (Troiani and Dawson 2017; Troiani 2017a,b). Overall conclusions of the larger global research project identify that through a local social, political, and historical lens the toolkit of the five themes can be applied to modern cities worldwide.

Unfinished buildings align with the failure to complete a perfect utopian and generic design vision of the modern city. Their regeneration signifies a shift to a more impermanent, fluid city 'with looser planning visions and design frameworks, linked to phased packages of smaller, often temporary initiatives, designed to unlock the potential of sites now, rather than in 10 years time' (Bishop and Williams 2012, p. 3). Impermanent, temporary, and ephemeral designs are challenging permanent and durable design visions (Ford 1997). 
While one could argue that designing such ephemeral projects is playing exactly in the hands of capitalism because the designs do not offer long-term social security to communities, who are forced to constantly change and adapt in response to decisions taken by very different people and government over which they have no control at all, we argue that this work is important because it reinstates the architect's practice as a socially motivated, not economically driven, practitioner. In order for a shift in the modern city to take place, the alternative practices used by the architect and presented here need to operate collaboratively with the users of the city and governance that oversee and determine the evolution of the city.

Returning for one moment to the maison domino, it is noteworthy that it was intended to engage both the architect and the users through an exchange of informal self-building. A form of emergency housing after the war, Jeanneret envisaged that:

it would be up to the individual owner to supply the missing parts of the bare skeleton; prefabricated window and wall sections would be made available in order to permit completion of every unit according to the needs of each dweller.

(von Moos 1983, p. 18)

Paul Emmons argues that the domino house was from its outset presented by Jeanneret to architects and owners as a site for creative participatory infill, cladding, and addition. It was never intended to be a fixed vision i mplemented by the a rchitect; instead it was an evolving schema. When an architect purposely designs into the construction process for a building a user engagement component, they open up a new mode of practice that goes beyond individual design authorship and autonomy. When a building frame is not completed it creates new design trajectories that challenge traditional authorship. Architects can learn many lessons on design for scarcity - rather than luxury - for positive wellbeing (Goodbun et al. 2012, 2014). New generations of architects trained in modes of flexible and open practice can be more capable and effective contributors to their urban environment and can be more sustainable in their own practice. Unfinished Athens is a lesson in forcing the collapse of the economically optimal, modernist grid (Figure 9.9). The research findings of the interrogation of the partially built concrete frame modern building that has been undertaken in Greece, Spain, Cuba and China will inform the forthcoming research on other cities. Future research will investigate the architect's practice in Western and Eastern cities, from neoliberal, individualistically motivated to collectively driven governance and the space in between in order to consider how architects can more positively contribute to urban development that is socially, mentally, and environmentally balanced.

\section{Acknowledgements}

The authors would like to thank Konstantinos Papadimitriou, Mando Moreti, Katerina Zisimopoulou, and Marcel Vellinga for their support for this research. 
$210 \mid 9$ Regenerating Unfinished Buildings

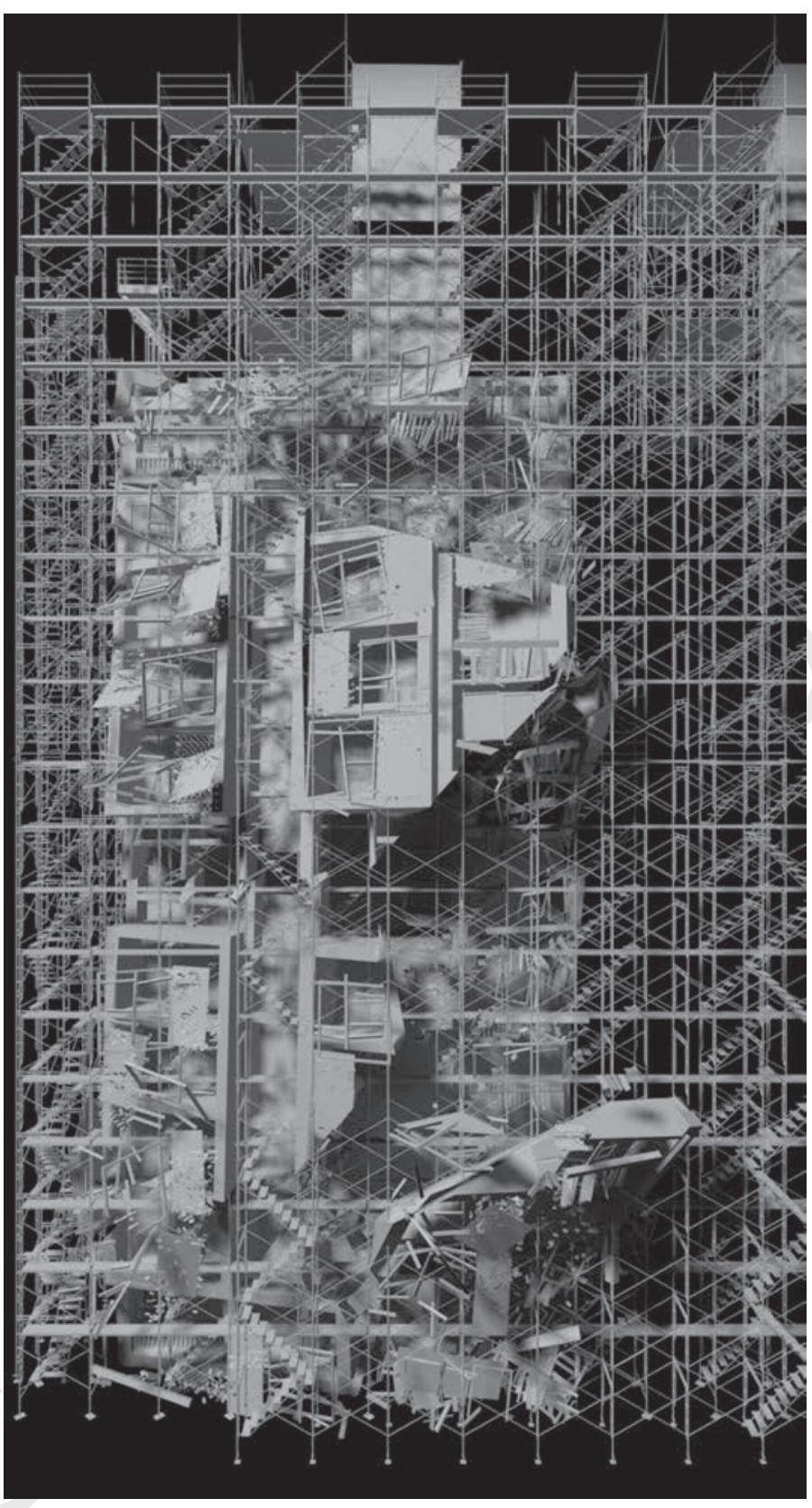

Figure 9.9 Grid Collapse Motion Study, Project title: 'A Modern Odyssey/ Ulysses' Curse'. Source: Project by Konstantinos Papadimitriou (March 2015). 


\section{Bibliography}

Alterazioni Video (2008). Incompiuto Siciliano or Sicilian Incompletion. Abitare 486: 190-207.

Amadeo, K. (2018). Greek Debt Crisis Explained. The Balance [Online]. 19 October. Available from: https://www.thebalance.com/what-is-the-greece-debt-crisis-3305525 [accessed 21 March 2019].

Architecture for Humanity (2006). Design Like You Give a Damn: Architectural Reponses to Humanitarian Crises. London: Thames and Hudson.

Architecture for Humanity (2012). Design Like You Give a Damn (2): Building Change from the Ground Up. New York: Abrams.

Aureli, P. V., (2011). Research projects: "Labor, City, Architecture: Towards a Common Architectural Language”. The Berlage [Online]. 1 July. Available from: http://www .theberlage.nl/galleries/projects/details/labor_city_architecture [accessed 21 March 2019].

Aureli, P. V. (2013). Pier Vittorio Aureli Theory And Ethos. Introduction by Todd Gannon for SCI-Arc, 23 January [Online]. Available from: https://www.youtube.com/watch? $\mathrm{v}=4$ pdcSjDrBDs [accessed 21 March 2019].

Aureli, P.V., Shéhérazade Giudici, M., and Issaias, P. (2012). From Dom-ino to polykatoikia. Domus 13: 70-79.

Ballesteros, M., Hwang, I., Sakamoto, T. et al. (eds.) (2008). Verb Crisis. New York: Actar Publishers (Lea edition).

Bennett, J. (2010). Vibrant Matter: A Political Ecology of Things. Durham, NC: Duke University Press.

Benton, T. and Cohen, J.-L. (2008). Le Corbusier Le Grand. London: Phaidon.

Bishop, P. and Williams, L. (2012). The Temporary City. Abingdon: Routledge.

Brand, S. (1997). How Buildings Learn: What Happens after They're Built. London: Phoenix.

Brillembourg, A. and Klumpner, H. (2012). Torre David: Informal Vertical Communities. London: Lars Muller.

Brillembourg, A., Kourkoula, K., Klumpner, H., and Kalagas, A. (eds.) (2017). Reactivate Athens: [101 Ideas]. Berlin: Ruby Press.

Crawford, M. (1999). Introduction. In: Everyday Urbanism (eds. J. Chase, M. Crawford and J. Kaliski), 8-15. New York: The Monacelli Press.

De Silvey, C. (2017). Curated Decay: Heritage Beyond Saving. Minneapolis, MN: University of Minnesota Press.

Deamer, P. (2014). Introduction. In: Architecture and Capitalism: 1845 to the Present (ed. P. Deamer), 1-7. London: Routledge.

Di Girolamo, G., (2008). Sicilian Incompletion (or Unfinished?) and the 'Project of the Future' [Online]. Available from: http://www.stardustudio.com/wp-content/uploads/2010/11/ Article-by-Giacomo-Di-Girolamo-for-Ebdaat.pdf [accessed 21 March 2019].

Dragonas, P. (2014). An obituary for the Greek City of repetition. MAS Context 21 'Repetition' (Spring 2014). Available from: http://www.mascontext.com/tag/polykatoikia [accessed 21 March 2019]. 
Dunham-Jones, E. (2014). Irrational exuberance: rem Koolhaas and the 1990s. In: Architecture and Capitalism: 1845 to the Present (ed. P. Deamer), 150-171. London: Routledge.

Emmons, P. (2012). The play of plans: Le Corbusier's serious game of dominoes. In: The Cultural Role of Architecture: Contemporary and Historical Perspectives (eds. P. Emmons, J. Lomholt and J. Hendrix), 132-140. London: Routledge.

Felici, B. (Director) (2011). Unfinished Italy. ZeLIG Films: Bolzano.

Flowers, B. (2014). Architecture in an Age of Uncertainty. In: Architecture in an Age of Uncertainty (ed. B. Flowers), -1, 10. Farnham, Surrey: Ashgate.

Ford, E. (1997). The theory and practice of impermanence. Harvard Design Magazine 73 (3) 'Durability and Ephemerality'. Available from: http://www.harvarddesignmagazine.org/ issues/3/the-theory-and-practice-of-impermanence [accessed 21 March 2019].

Foucault, M. (1977). Discipline and Punish: The Birth of the Prison. New York: Pantheon Books.

Fuenmayor, J. (2011). The tower of David. Domus 28 April. Available from: http://www .domusweb.it/en/architecture/2011/04/28/the-tower-of-david.html [accessed 21 March 2019].

Garrett, B.L. (2013). Explore Everything: Place-Hacking the City. London: Verso Books.

Giddens, A. (2014). Turbulent and Mighty Continent: What Future for Europe? Cambridge: Polity.

Goodbun, J., Till, J., and Iossifova, D. (eds.) (2012). Scarcity: Architecture in an Age of Depleting Resources. London: Wiley.

Goodbun, J., Klein, M., Rumpfhuber, A., and Till, J. (2014). The Design of Scarcity. Strelka Press.

Guattari, F. (2014/1989). The Three Ecologies. London: Bloomsbury Publishing.

Handa, R. (2015). Allure of the Incomplete, Imperfect and Impermanent: Designing and Appreciating Architecture as Nature. London/New York: Routledge.

Hardt, M. and Negri, A. (2000). Empire. Cambridge, MA/London: Harvard University Press.

Issaias, P., (2016). On Conflict, Generic and the Informal: the Greek Case. The City as a Project Research Collective, 27 January, First published in Very Vary Veri, Harvard GSD, Issue 2 (2015) Available from: http://thecityasaproject.org/2016/01/on-conflict-generic-and-theinformal-the-greek-case [accessed 21 March 2019].

Jégou, F., Bonneau, M., Tytgadt, E., et al. (2016). REFILL: Reuse of vacant spaces as driving Force for Innovation on Local Level (Baseline Study). Available from: https://urbact.eu/sites/ default/files/refill_baseline_study.pdf.

Kazakos, P. (2009). Between State and Markets: Economy and Economic Policy in Greece, 1944-2000. Athens: Patakis.

King, E.A. (2011) Artists \& Environmental Change: The Elusive Power of Contemporary Art, Artes Magazine, 14 October. Available from: http://www.artesmagazine.com/?p=6598 [accessed November 2019].

Kingsnorth, P. and Hine, D. (2009). Uncivilisation: Dark Mountain Manifesto. Dark Mountain Project.

Kneer, M. and Schwartz, D. (Directors) (2013). Torre David: The World's Tallest Squat. Venezuela: Switzerland.

Kotzamanis, V. (1997). Athens 1848-1995. The demographic emergence of a Metropolis. The Greek Review of Social Research 5: 92-93. 
Levine, N. (2006). The architecture of the unfinished and the example of Louis Kahn. In: Fragments Architecture and the Unfinished: Essays Presented by Robin Middleton (eds. B. Bergdoll and W. Oechslin), 323-342. London: Thames and Hudson.

Lubow, A., (2000). Rem Koolhaas Builds. The New York Times Magazine [Online]. 9 July. Available from: https://www.nytimes.com/2000/07/09/magazine/rem-koolhaas-builds.html [accessed 21 March 2019].

Mangold, W. (2014). Architecture and the vicissitudes of capitalism. In: Architecture in an Age of Uncertainty (ed. B. Flowers), 15-24. Farnham, Surrey: Ashgate.

Masu, A. and D'Aita, C., (2010). Festival dell'Incompiuto Siciliano (Incompiuto Siciliano Festival), translated by P. Arboleda [accessed 21 March 2019].

Melvin, D., (2015). Between rock, hard place, Greece picks austerity. How did it get into this mess? CNN World [Online]. 13 July. Available from: https://edition-m.cnn.com/2015/07/13/ europe/how-greece-reached-this-point/index.html [accessed 21 March 2019].

Mistriotis, V. and Vandoros, A. (eds.) (2010). Piraeus Tower 2010: Changing the Face/Facades Reformation. digital catalogue produced by GreekArchitects.gr.

Oswalt, P., Overmeyer, K., and Misselwitz, P. (2013). Urban Catalyst: The Power of Temporary Use. Berlin: DOM Publishers.

Owen, G. (ed.) (2009). Architecture, Ethics and Globalization. London and New York: Routledge.

Pérez de Arce, R. (2015). Urban Transformations and the Architecture of Additions. Abingdon, Oxon: Routledge.

Philippidis, D. (1984). Neohellenic Architecture. Athens: Melissa.

Riether, G. (2014). Lightweight, impermanent, recycled. In: Architecture in an Age of Uncertainty (ed. B. Flowers). Farnham, Surrey: Ashgate, Chapter 5.

Spencer, D. (2016). The Architecture of Neoliberalism: How Contemporary Architecture Became an Instrument of Control and Compliance. London: Bloomsbury Academic.

St Hill, C. (ed.) (2016). This Is Temporary: How Transient Projects Are Redefining Architecture. London: RIBA Publishing.

Themelis, S. (2015). From mainstream politics to social movements: Greece in between austerity and hope. Discover Society 27. Available from: https://discoversociety.org/2015/12/ 01/from-mainstream-politics-to-social-movements-greece-in-between-austerity-and-hope [accessed 21 March 2019].

Theocharopoulou, I. and Frampton, K. (2017). Builders, Housewives and the Construction of Modern Athens. London: Black Dog Publishing Limited.

Troiani, I. (ed.) (2017a). Unfinished Athens. Blurb. www.blurb.co.uk/b/8002074-unfinishedathens.

Troiani, I. (ed.) (2017b). Unfinished Cuba. Blurb. www.blurb.co.uk/b/7986231-unfinishedcuba.

Troiani, I. and Dawson, A. (eds.) (2017). Unfinished Madrid. Blurb. www.blurb.co.uk/b/ 8260202-unfinished-madrid.

Van der Hoorn, M. (2009). Indispensable Eyesores: An Anthropology of Undesired Buildings. New York: Berghahn Books.

Van Hinte, E., Peeren, C., and Jongert, J. (2007). Superuse: Constructing New Architecture by Shortcutting Material Flows. Rotterdam: 010 Publishers. 
Vesely, D. (2006). The nature of the modern fragment and the sense of wholeness. In: Fragments Architecture and the Unfinished: Essays Presented by Robin Middleton (eds. B. Bergdoll and W. Oechslin), 43-56. London: Thames and Hudson.

Virilio, P. (2008). Bringing the Unliveable alive. Abitare Magazine 486: 207.

Von Moos, S. (1983). Le Corbusier: Elements of Synthesis. First published in 1968 in Germany, 18. Cambridge, MA: MIT Press.

Wilson, C. (2011). The lure of pop-ups: low budgets, tight deadlines, and impermanence ought to be turnoffs, but architects and designers love these temporary projects. Oculus 73 (3). 